\title{
Modulation of convection in the southwestern Amazon basin by extratropical stationary fronts
}

\author{
Thomas M. Rickenbach \\ Joint Center for Earth Systems Technology (JCET), University of Maryland, Baltimore County and NASA Goddard Space \\ Flight Center (GSFC) Mesoscale Processes Branch, Greenbelt, Maryland, USA
}

\section{Rosana Nieto Ferreira}

Goddard Earth Sciences and Technology Center (GEST), University of Maryland, Baltimore County and NASA Seasonal to Interannual Prediction Project/GSFC, Greenbelt, Maryland, USA

\section{Jeffrey B. Halverson}

Joint Center for Earth Systems Technology (JCET), University of Maryland, Baltimore County and NASA Goddard Space Flight Center (GSFC) Mesoscale Processes Branch, Greenbelt, Maryland, USA

Dirceu Luis Herdies ${ }^{1}$

Goddard Earth Sciences and Technology Center (GEST), University of Maryland, Baltimore County and NASA Data Assimilation Office/GSFC, Greenbelt, Maryland, USA

\author{
Maria A. F. Silva Dias \\ Department of Atmospheric Science, Institute of Astronomy and Geophysics, University of São Paulo, São Paulo, Brazil \\ Received 15 December 2000; revised 5 October 2001; accepted 15 October 2001; published 22 August 2002.
}

[1] Regimes of lower tropospheric northwesterly wind observed in southwestern Amazônia during the Tropical Rainfall Measuring Mission Large-Scale Biosphere Atmosphere (TRMM-LBA) field campaign were shown to be local manifestations of stationary frontal systems that extended into the deep Tropics along the South Atlantic Convergence Zone ("SACZ" regime). Frontal systems were transient and were confined to the subtropics during the interim periods of easterly and weak westerly flow ("nonSACZ" regime). Observations from surface-based radar in TRMM-LBA suggested that mesoscale convective systems in the SACZ regime were significantly larger in areal coverage, with weaker rainfall intensity and weaker vertical development of the convective cells. The diurnal variation of rain intensity and rain areal coverage generally showed afternoon maxima for both regimes, but with important differences suggesting explosive convective cell growth in the non-SACZ regime and the dominance of nocturnal stratiform rain processes in the SACZ regime. These results had implications for the parameterization (in general circulation models) of subgrid-scale convective processes in Amazônia in terms of the large-scale flow and for improving precipitation and latent heating retrieval from spaceborne platforms such as the TRMM satellite. INDEX TERMS: 3374 Meteorology and Atmospheric Dynamics: Tropical meteorology; 3314 Meteorology and Atmospheric Dynamics: Convective processes; 3329 Meteorology and Atmospheric Dynamics: Mesoscale meteorology; KEYWORDS: Convection, Tropics, Amazon, Monsoon, Low-level jet, TRMM

\section{Introduction}

[2] The recent Tropical Rainfall Measuring Mission Large-Scale Biosphere Atmosphere (TRMM-LBA) Wet Season Amazon Mesoscale Campaign (WET-AMC) field campaign (hereafter TRMM-LBA) in the Brazilian state of Rondônia from January to February 1999 provided a

\footnotetext{
${ }^{1}$ Permanently at Centro de Previsão de Tempo e Estudos Climaticos/ Instituto de Pesquisas Espaciais (CPTEC/INPE), Cachoeira Paulista, Brazil.

Copyright 2002 by the American Geophysical Union. 0148-0227/02/2000JD000263\$09.00
}

detailed view of mesoscale convection over the southwestern Amazon basin during austral summer [Silva Dias et al., 2002a]. A primary goal of this experiment was to integrate our understanding of the hydrological cycle in Amazônia, from the synoptic scale to the scale of individual convective systems. The present study addressed the relationship between variability of the synoptic-scale flow patterns over South America and changes in the local mesoscale properties of convection in southwestern Amazônia. These mesoscale properties included precipitation intensity, rainfall areal coverage, convective cell versus stratiform rainfall fraction, and vertical reflectivity structure. Herein we show that distinct regimes in the low-level wind direction 
(westerly versus easterly) over the TRMM-LBA were influenced by the penetration of the circulations associated with stationary fronts into the deep Tropics. These regimes were associated with important differences in the mesoscale properties of convective systems. These results suggested that latent heating retrieval based on cloudresolving model simulations [Olson et al., 1999], one of the goals of the TRMM program, should account for regional variability of the large-scale circulation. Another application of this study was to form a basis to test and to improve the parameterization of subgrid-scale convective processes (over tropical South America) with respect to the large-scale flow in global or regional scale models.

[3] Aside from the strong diurnal cycle of rainfall, previous studies have suggested that convective variability over Amazônia is modulated by extratropical baroclinic wave activity. Liebmann et al. [1999] studied summertime variability of convection over South America and adjoining portions of the Atlantic Ocean using a 17-season long record of outgoing longwave radiation (OLR, a proxy for deep convection). They found that the OLR variance in the southwestern and central Amazon basin was dominated by timescales of 2-30 days, with strong peaks in the OLR spectrum at 9 and 12 days. Liebmann et al. [1999] associated these spectral peaks with the modulation of convection by strong midlatitude cold fronts that often penetrate into tropical latitudes. Along the eastern slope of the Andes Mountains, baroclinic waves produce intrusions of cold air into the Tropics that organize synoptic scale bands of deep convection moving equatorward along the frontal boundary [Garreaud, 2000]. Ahead of these fronts, low-level northwesterly flow extends from the Tropics into the midlatitudes. Even though these systems occur all year-round, tropical convection along these frontal boundaries is strongest during austral summer, when low-level convergence is embedded in a conditionally unstable environment [Garreaud, 2000]. Low frequency variability, such as that associated with the 30-60 day Madden-Julian oscillation (MJO), appeared to be of secondary importance compared to the influence of higher frequency phenomena. Zhao and Weare [1998] suggested that the strong diurnal variability of Amazon convection damped lower frequency variability in that region.

[4] During the summertime, fronts often become stationary for several days over the southeast Brazilian coast, producing a synoptic scale feature known as the South Atlantic Convergence Zone (SACZ). Individual SACZ episodes may last for about one week, and are composed of one or several midlatitude cold fronts that intrude into the Tropics and become stationary over southeastern Brazil. Previous studies have suggested that the mean climatological position of the SACZ is determined by the Amazon basin convection [Figueroa et al., 1995]. On the other hand, the strong intraseasonal and interannual variability of the position and strength of the SACZ are caused by variations in baroclinic wave activity that originate in the extratropical Pacific Ocean [Liebmann et al., 1999]. A link between variability in the SACZ and the intraseasonal oscillation was suggested by the presence of 30-60 day peaks in OLR variability in the SACZ shown by Liebmann et al. [1999]. This connection occurs through a Rossby waveguide in the Pacific Ocean [Casarin and Kousky, 1986; Grimm and Silva Dias, 1995; Nogues-Paegle and Mo, 1997].
[5] Nogues-Paegle and Mo [1997] discussed the anticorrelation between a well-defined SACZ and precipitation in the subtropical plains of Argentina. When the SACZ is present, moisture transport from the Tropics is diverted eastward, away from the plains of Argentina and toward southeastern Brazil, along the stationary frontal zone associated with the SACZ. This eastward shift in moisture transport during SACZ periods is thought to be related to an eastward displacement of the South American low-level jet, away from its typical position along the eastern foothills of the Andes Mountains [Marengo et al., 2001].

[6] These studies suggested that modulations in the South American low-level jet by baroclinic systems may provide a connection between the SACZ and convection in tropical South America. The present study examines this connection by hypothesizing that changes in the statistical properties of mesoscale convection in southwestern Amazônia were linked to low-level northwesterly flow (related to the lowlevel jet) associated with a well-established SACZ. The size, rain intensity, fraction of convective cell precipitation and vertical structure of the convection in the southwestern Amazon basin, were strongly influenced by the degree to which stationary frontal systems (the SACZ) penetrated equatorward. The TRMM-LBA experiment and the data used in this study are briefly described in section 2. Local wind regimes in the TRMM-LBA region are discussed in section 3 and are related to large-scale flow features and patterns of large-scale cloudiness. In section 4, statistics and time series from an analysis of convective systems observed by radar in southwestern Amazônia are related to the wind regimes. A discussion of how changes in circulation associated with the establishment of the SACZ might lead to the observed regimes of mesoscale convection is discussed in section 5 .

\section{Data}

[7] A network of radar and sounding instrumentation (Figure 1) was operated continuously during the TRMMLBA field campaign, from mid-January to the end of February 1999 (Silva Dias et al. [2002a] provided details of all components of the experiment). Two ground-based scanning Doppler radars, the NASA/NOAA TOGA C-band radar and the NCAR SPOL polarimetric S-band radar, sampled the internal precipitation structure, rainfall intensity, and radial velocity of precipitation systems. This study focused on statistics of radar reflectivity from the TOGA radar. The local variation of tropospheric winds was estimated from radiosonde data taken from the Abracos site, several kilometers west of the TOGA radar location (see Halverson et al. [2002] for details). Radiosondes were launched at Abracos nominally every three hours.

[8] Data from the TOGA radar were used to produce Cartesian volumes $(1 \mathrm{~km} \times 1 \mathrm{~km} \times 1 \mathrm{~km}$ spacing $)$ of radar reflectivity, extending to a circular area of radius $130 \mathrm{~km}$ centered on the radar. Reflectivity data was corrected for time-dependent calibration shifts, based on intercomparisons with the TRMM satellite precipitation radar [Anagnostou et al., 2001]. Nonmeteorological echoes associated with anomalous propagation, range aliasing, and ground clutter were removed with a semiautomated technique which is described by Marks et al. [2000]. These reflectivity volumes 


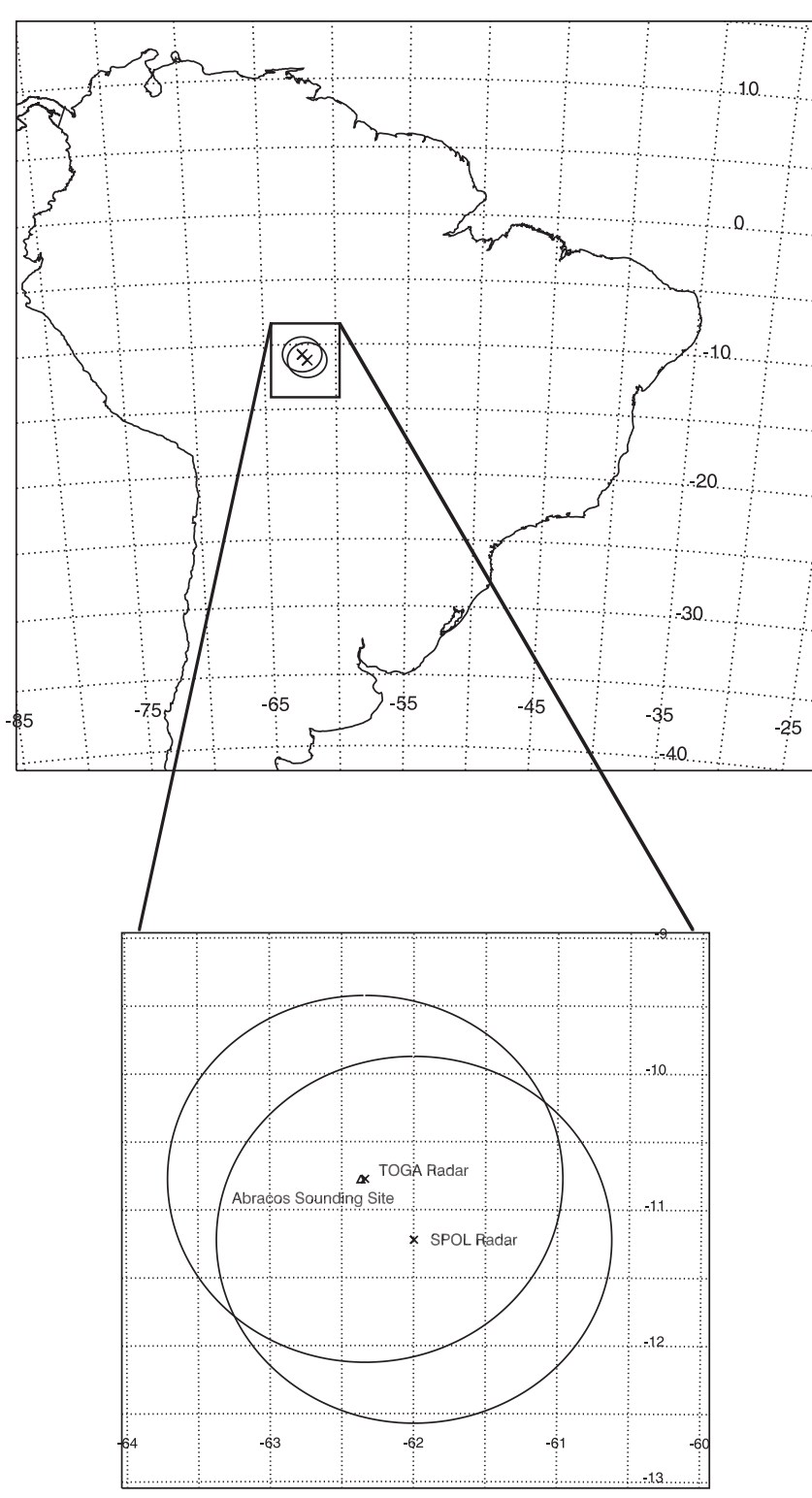

Figure 1. Scanning radar network and Abracos sounding location for the TRMM-LBA experiment. Circles indicate $150 \mathrm{~km}$ range from the TOGA C-band and SPOL S-band radars and " $\mathrm{x}$ " marks the location of each radar with respect to the South American continent and the TRMM-LBA domain. The triangle shows the location of the Abracos sounding site.

were used to produce time series of precipitation areal coverage and relative rainfall intensity at 10 -min intervals at a height of $2 \mathrm{~km}$ above ground level. It is important to distinguish between the convective cell and stratiform portions of mesoscale precipitation systems. The relative amount of rainfall from each component is related to the evolution of the system and to the manner in which latent heat is distributed in the troposphere [Houze, 1989]. An algorithm to separate convective cells from the more homogeneous regions of stratiform rainfall [Steiner et al., 1995; Rickenbach and Rutledge, 1998] was applied to the reflectivity field. Mean vertical profiles of radar reflectivity were constructed for convective and stratiform portions of the reflectivity field. An empirical relationship between radar reflectivity and rainfall, derived from surface drop-size distribution data [Tokay et al., 2002], was used to convert reflectivity to an estimate of areal mean precipitation rate at $2 \mathrm{~km}$ height. Rainfall areal coverage was defined as the area covered by reflectivity values of at least $10 \mathrm{dBZ}$ (nominally $0.5 \mathrm{~mm} \mathrm{hr}^{-1}$ ). There is much uncertainty in rainfall retrieval from C-band radar reflectivity data due to attenuation, beam filling errors, and limited measurements of the distribution of precipitation particle sizes. For this reason, only relative variations in the rainfall time series will be emphasized in this work.

[9] In order to examine the cloudiness distribution over South America, a half-hourly global infrared data set $(14 \mathrm{~km}$ resolution), was obtained from the Global Hydrology Resource Center (GHRC) at the Global Hydrology and Climate Center. We extracted a subset of the global array of infrared brightness temperatures over South America to examine the presence and motion of midlatitude baroclinic systems and to produce composite maps of infrared percent high cloudiness. A cloud top temperature threshold of $230 \mathrm{~K}$ was chosen to extract high cloudiness representative of deep convection and associated mesoscale anvil cloud. This value was close to the $235 \mathrm{~K}$ threshold used by Laurent et al. [2002] to describe cloudiness from mesoscale convective systems over the Amazon basin during TRMM-LBA.

[10] Data from the NASA Data Assimilation Office (DAO) GEOS-2 data assimilation system analysis [Chen et al., 1999] was used to establish the large-scale flow features over South America during TRMM-LBA. The DAO analysis is a data assimilation simulation carried out at a horizontal resolution of $2.0^{\circ}$ latitude by $2.5^{\circ}$ longitude. The upper air analysis incorporated data from rawinsondes, dropwindsondes, aircraft winds, cloud-tracked winds, and satellite-derived thickness. The DAO simulations did not assimilate soundings taken as a part of the TRMM-LBA field campaign, and thus provided an independent estimate of the local wind field.

\section{Local and Large-Scale Wind Regimes}

[11] In this section, we explored relationships between wind regimes observed locally at the Abracos site and the large-scale circulation patterns over South America. In particular, we focused on the effect of stationary midlatitude frontal systems on local wind variation in the TRMM-LBA region. The local wind regimes were illustrated with sounding data from the Abracos pasture site, near the TOGA radar. The large-scale flow was represented by the DAO analysis.

\subsection{Local Wind Regimes}

[12] Sounding data from Abracos were used to construct time series of the zonal and meridional wind components (Figure 2). Gaps in the time series of up to one day were filled with linear interpolation of surrounding data points. A significant feature of the zonal wind time series (Figure 2a) was alternating periods of westerly (shaded) and easterly winds in the lower and middle troposphere. Most conspicuous were two periods (each nearly one week long) of sustained westerly winds in mid-January and late February, separated by about 40 days. Westerly flow in these periods 
A

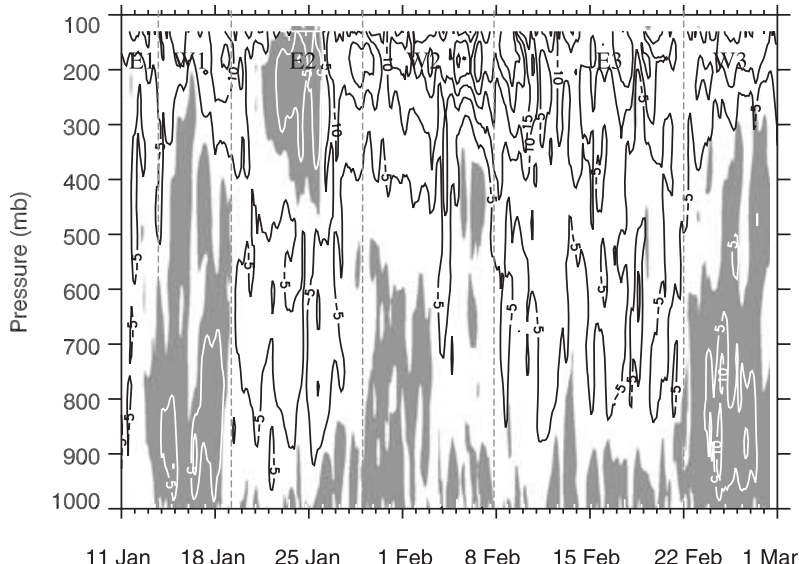

B

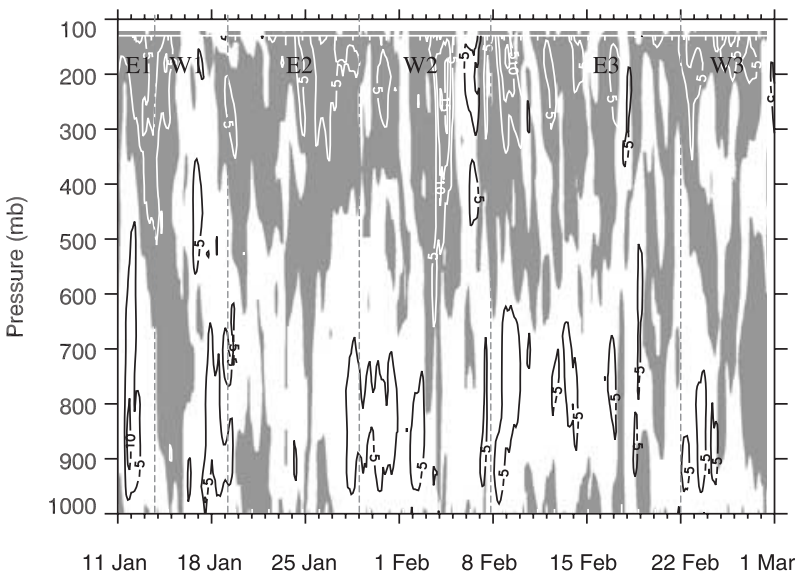

Figure 2. Time series of the (a) zonal wind (westerlies shaded) and (b) meridional wind (southerlies shaded) from the Abracos site sounding data. Regime periods (see text) are indicated with dashed vertical lines and labels. Units are $\mathrm{m} \mathrm{s}^{-1}$ and contour interval is $5 \mathrm{~m} \mathrm{~s}^{-1}$.

extended from the surface to the upper troposphere. In the intervening periods, winds were generally easterly in the midtroposphere with variable winds below $900 \mathrm{mb}$. The exception was a period in late January and early February where weak westerly winds extended to the midtroposphere, though not as well defined as the other two westerly periods. The meridional wind field (Figure $2 b$ ) in general was northerly in the lower troposphere and southerly (shaded) in the upper troposphere. Notable deviations from this pattern included alternating periods of southerly and northerly winds in the upper troposphere in early February (see section 3.2), and southerly winds in the midtroposphere in mid-January and late February.

[13] The zonal component of the wind was used to define wind regime periods, for the purpose of composite analysis, in the following way. A westerly regime was defined when westerly winds extended from the surface to $800 \mathrm{mb}$ for at least three consecutive days. The interim periods were defined as easterly regimes. Two major and one minor westerly wind episodes were characterized by a deep layer of westerly winds extending from the surface to at least 400 $\mathrm{mb}$. The first major westerly wind period (hereafter referred to as W1) began on 14 January and lasted until January 19 (Figure 2a). A second, weaker, episode of westerly winds
(W2) occurred from 29 January to 8 February. The other major westerly wind episode (W3) began on 22 February and ended on 1 March (DAO analysis data suggested that W3 continued through the first week of March, however the regime definitions were limited to the availability of radar data). In general, the onset of westerly winds occurred in the lower troposphere and extended upward with time. During the interim periods, low-level easterly winds (E1: 11-14 January; E2: 19-29 January; E3: 8-22 February) prevailed in the midtroposphere. These regime periods are listed in Table 1.

[14] To summarize, the overall pattern of wind variability was one of alternating periods of northwesterly and northeasterly winds in the lower troposphere. In general, upper tropospheric winds were southeasterly, except during E2 where the flow was southwesterly. These local wind regimes were clearly evident in wind time series extracted from the DAO analysis over the TRMM-LBA region [Herdies et al., 2002]. Since the TRMM-LBA sounding data were not assimilated into the DAO analysis, the sounding data provided an independent check that the DAO analysis captured the local wind variations in the TRMM-LBA region and lent credence to the DAO composite analysis shown in the next section.

\subsection{Large-Scale Circulation and Stationary Fronts}

[15] In this section, we present evidence that the two strong westerly wind periods (W1 and W3) were local manifestations of continental scale circulation variability due to stationary fronts (associated with the SACZ) extending into the Tropics. Composites of DAO winds at $850 \mathrm{mb}$ and $200 \mathrm{mb}$, infrared cloud patterns, and observations of frontal positions were used to support this hypothesis.

[16] Observations of the movement of baroclinic frontal zones during TRMM-LBA were reported in the Brazilian Space Agency's Monthly Climate Bulletin [Climanálise, 1999]. Cold fronts typically propagated northeastward in succession along the southeastern Brazilian coast, extending into the interior of the continent. Shown in Figure 3 is a time series of the distance traveled by individual frontal systems each day during the TRMM-LBA period, as observed by stations along the coast, based on data provided by Climanálise [1999]. Each frontal system was readily identified by animations of the infrared cloudiness imagery used in this study. Values of zero indicated that the front was stationary for that day. Figure 3 showed that the occurrence of stationary fronts for several consecutive days coincided remarkably

Table 1. List of Periods Defined by Lower Tropospheric Zonal Flow Direction, Where "E" is Easterly Flow and "W" is Westerly Flow $^{\mathrm{a}}$

\begin{tabular}{cc}
\hline \multicolumn{2}{c}{ Zonal wind regime periods } \\
\hline Period & Date \\
\hline E1: "non-SACZ" period & 11-14 January $00 Z$ \\
W1: "SACZ" period & 14-19 January 00Z \\
E2: "non-SACZ" period & 19-29 January 00Z \\
W2: "non-SACZ" period & 29 January to 8 February 00Z \\
E3: "non-SACZ" period & $8-22$ February 00Z \\
W3: "SACZ" period & 22 February to 1 March 00Z \\
\hline
\end{tabular}

"The "SACZ" and "non-SACZ" description is based on discussion in section 3.2 . 


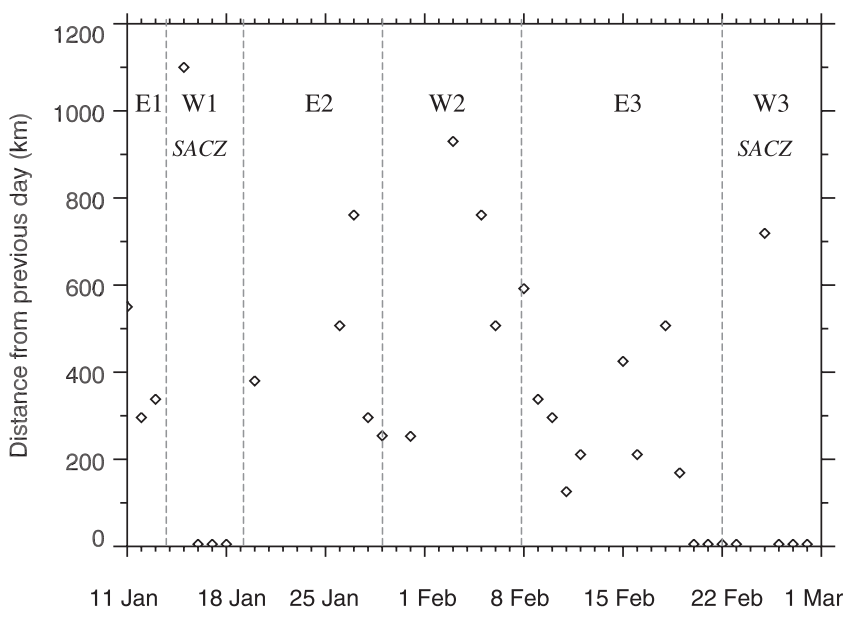

Figure 3. Time series of the daily movement of frontal systems, observed at various locations along the coast of southeastern Brazil between $35^{\circ} \mathrm{S}$ and $20^{\circ} \mathrm{S}$ latitude (based on analysis presented by Climanálise [1999]). Regime periods are shown with dashed vertical lines and labels.

with the two strong westerly wind periods (W1 and W3) in the TRMM-LBA region. This suggested a relationship between the strong local westerly flow in southwest Amazônia and stationary extratropical frontal systems. Based on discussion in section 1, the presence of fronts that become stationary over southeast Brazil for several days is a hallmark of the SACZ. We will therefore refer to the combination of $\mathrm{W} 1$ and $\mathrm{W} 3$ as the "SACZ" period, and the easterly regimes (E1, E2, and E3) combined with the weak westerly regime (W2) as the "non-SACZ" period (Table 1). At this point it is worth stating that the results shown in the next sections were not very sensitive to whether W2 was included in the nonSACZ period, so that the contrast between SACZ and nonSACZ regimes was similar to the contrast between easterly and westerly flow regimes.

[17] In order to explore the relationship between the establishment of the SACZ and the local strong westerly wind periods, composites of the DAO analysis winds were examined for the SACZ and non-SACZ periods. In both composites, lower tropospheric $(850 \mathrm{mb})$ easterly winds associated with the South Atlantic High extended across the Amazon basin. The SACZ composite (Figure 4) revealed a strong $850 \mathrm{mb}$ northwesterly flow feature emanating from the deep Tropics into the midlatitudes passing through and east of the TRMM-LBA region. The main axis of the northwesterly flow extended from southwestern Amazônia to the southeast and entered the Atlantic Ocean in the vicinity of $25^{\circ} \mathrm{S}, 50^{\circ} \mathrm{W}$ (near the city of São Paulo, Brazil). In contrast, the non-SACZ composite

Figure 4. (opposite) Composite of DAO wind data at 200 and $850 \mathrm{mb}$ for the SACZ regime periods. Scale indicates, for 200 and $850 \mathrm{mb}$, the length of a 50 and $25 \mathrm{~m} \mathrm{~s}^{-1}$ wind vector, respectively. The TRMM-LBA radar domain is located at approximately $10^{\circ} \mathrm{S}, 62.5^{\circ} \mathrm{W}$ and is shown by an open circle.
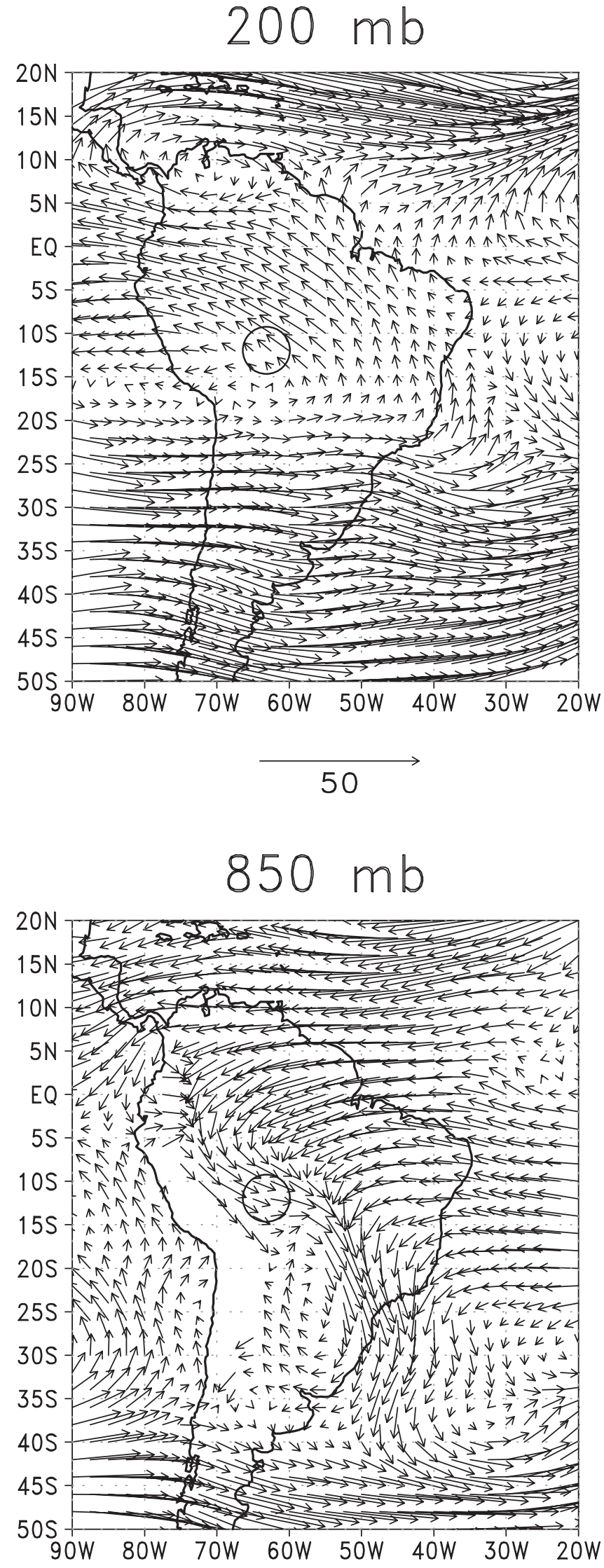
(Figure 5) showed tropical easterlies extending through the TRMM-LBA area to the foothills region, so that the northwesterly flow was restricted to the Andes foothills. Blocking of the low-level flow by the mountains tended to produce northwesterly winds along the foothill region east of the Andes [Gandu and Geisler, 1992]. In fact, at $20^{\circ} \mathrm{S}$ latitude the SACZ composite low-level northerly jet was displaced nearly $1500 \mathrm{~km}$ eastward of its position in the non-SACZ composite. This change in position of the lowlevel northerly jet had important consequences for the hydrological balance over South America, as discussed by Herdies et al. [2002]. The $850 \mathrm{mb}$ wind composites were consistent with local wind observations at the Abracos site.

[18] In both composites the dominant feature at $200 \mathrm{mb}$ was the Bolivian High, centered near $20^{\circ} \mathrm{S}$, a well-known feature of the summer circulation over South America [Silva Dias et al., 1983]. The circulation around the Bolivian High produced southeasterly winds over the central and western Amazon basin which dominated the upper-level flow in the TRMM-LBA region, consistent with the sounding data. When compared to its counterpart in the SACZ composite, the non-SACZ composite Bolivian High had a more clearly defined closed circulation, and was shifted poleward by about $5^{\circ}$. The non-SACZ composite revealed a well-defined upper-level trough over Northeast Brazil. This was possibly due to the presence of stronger upper-level anticyclonic shear in the non-SACZ composite. (These upper tropospheric cyclones form near the core of the South Atlantic midoceanic trough and propagate northwestward toward Northeast Brazil [Kousky and Gan, 1981]. They can be thought of as extrusions of high potential vorticity midlatitude air into the Tropics through a Rossby wave breaking process that involves trough thinning in regions of enhanced anticyclonic wind shear [Thorncroft et al., 1993].) In the SACZ composite a weaker upper-level trough was located over the Atlantic Ocean, which did not extend equatorward of $15^{\circ} \mathrm{S}$ latitude.

[19] At this point, some discussion of the distinction between the weak westerly wind period (W2) and the SACZ regime (W1 and W3) is useful. The DAO wind composite for W2 (not shown) also contained the northwesterly flow branch extending poleward from the deep Tropics. However, the W2 and SACZ wind composites differed in two important regards suggesting that the westerly flow in W2 was unrelated to the SACZ. First, northwesterly flow in W2 was restricted to the foothills of the Andes, mainly west of the TRMM-LBA area, and did not extend eastward away from the mountains. Second, the $200 \mathrm{mb}$ trough over NE Brazil was a closed cyclonic circulation, which propagated westward during the first week of February in the W2 DAO and cloudiness fields. The local signature of these propagating cyclones may be seen in the meridional winds from the Abracos sounding data (Figure 2b). The winds in the upper troposphere shifted from southerly to northerly between 4 and 7 February, consistent with the westward propagation of an upper-level cyclonic circulation. The convergence on the leading edge of these travelling upper-level cyclones have been shown to suppress the occurrence of deep convection as they travel westward [Kousky and Gan, 1981], which may have inhibited the establishment of a stationary front during W2.
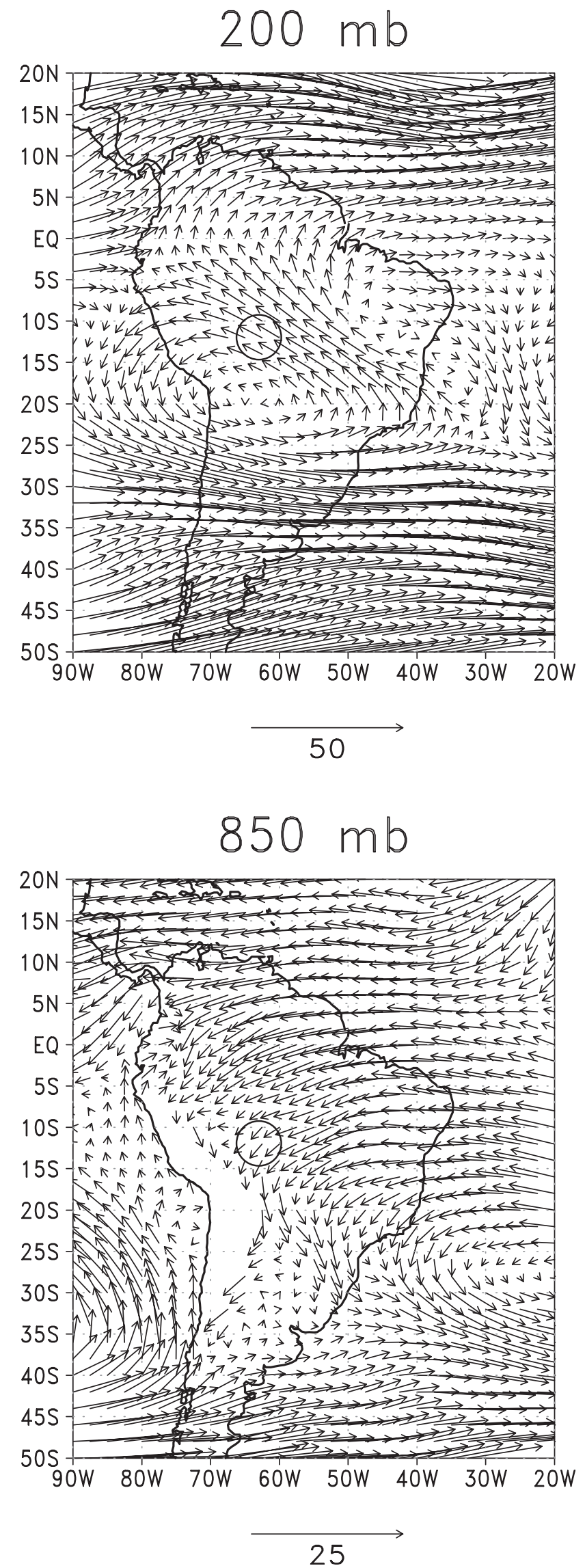

Figure 5. As in Figure 4, but composited for the non$\mathrm{SACZ}$ regime periods. 

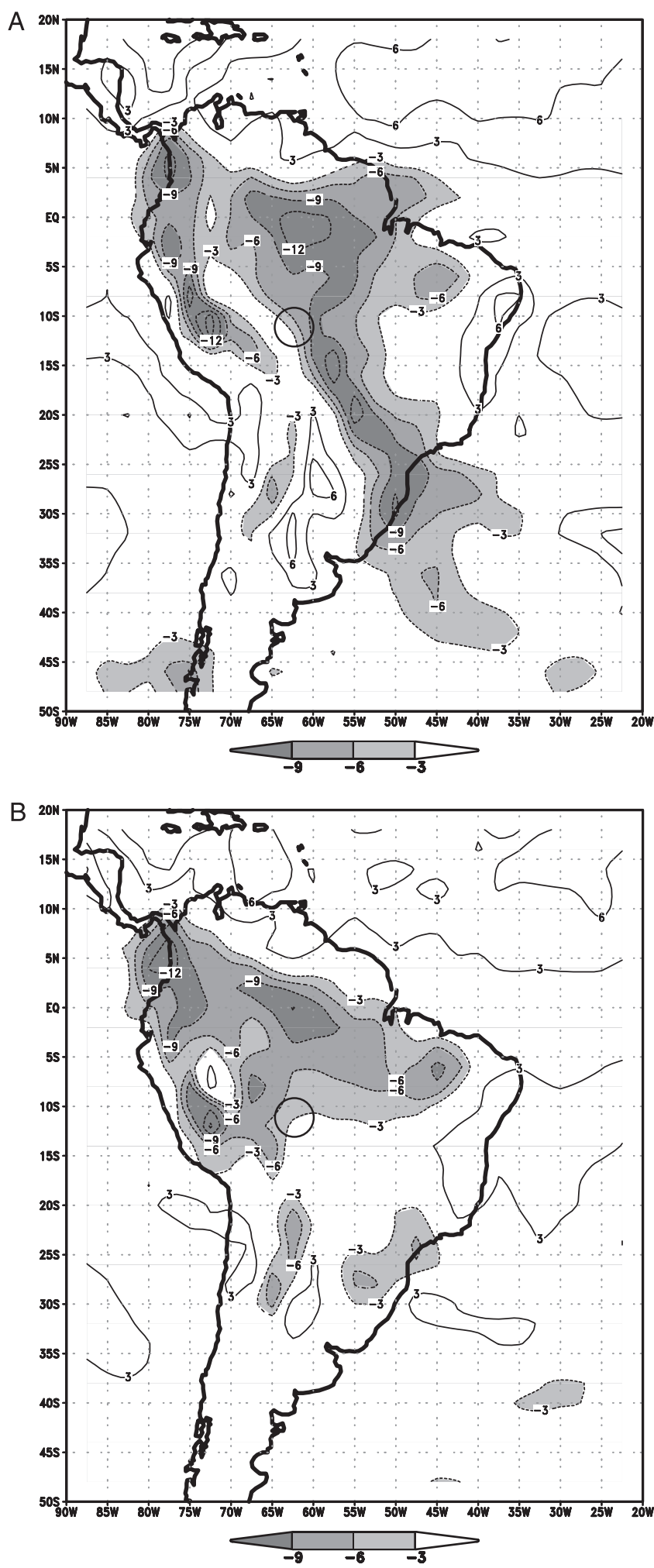

Figure 6. Composites of vertically integrated moisture convergence $\left(10^{-5} \mathrm{~mm} \mathrm{~s}^{-1}\right)$ from the DAO analysis for (a) the SACZ regime periods and (b) the non-SACZ regime periods. The TRMM-LBA radar domain is located at approximately $10^{\circ} \mathrm{S}, 62.5^{\circ} \mathrm{W}$ and is shown by an open circle.
[20] The northwesterly flow in the SACZ composites appeared to serve as a conduit for moisture transport out of the Tropics along the SACZ, as suggested by Lenters and Cook [1999]. This was illustrated by the SACZ and nonSACZ composites of vertically integrated moisture convergence, taken from the DAO analysis (Figure 6). The main axis of moisture convergence in the SACZ composite extended from the deep Tropics southeastward to the Atlantic Ocean, and corresponded to the location of the northwesterly flow branch. This feature was not present in the non-SACZ composite, suggesting that tropical moisture did not extend into the subtropics. A northwest-southeast oriented elongated region of low-level convergence, responsible for the colocated maximum in vertically integrated moisture convergence, was a characteristic signature of the SACZ [Kodama, 1992].

[21] Composites of infrared percent high cloudiness (PHC) (Figure 7) provided further, independent evidence that the northwesterly flow feature was associated with the SACZ. The PHC composite for the SACZ regime showed a mass of deep cloud extending southeastward out of the Tropics and into the Atlantic Ocean. This cloud band (the SACZ) was collocated with the axis of northwesterly flow and moisture convergence from the DAO composites. Note also the contrast between the SACZ cloudiness and the clear region in the La Plata river basin (along $55^{\circ} \mathrm{W}$ longitude in the subtropics), reminiscent of the dipole discussed by Nogues-Paegle and Mo [1997]. None of these features were present in the non-SACZ PHC composite. Instead, high cloudiness was generally less common and distributed more evenly in the subtropics. Animation of infrared cloud imagery as well as the propagation of individual frontal systems shown in Figure 3 showed that frontal systems were in fact present in the non-SACZ regime. The important distinction was that these fronts were not stationary, and did not penetrate into the tropical regions in contrast with the SACZ regime stationary fronts.

[22] In summary, the DAO wind and moisture convergence composites, daily frontal propagation, and infrared cloudiness patterns supported the hypothesis that the strong westerly wind periods in the TRMM-LBA region were local manifestations of stationary frontal systems associated with the SACZ which penetrated into the deep Tropics. In the presence of stationary frontal regions characteristic of the SACZ, northwesterly low-level winds were produced in southwestern Amazônia along the frontal zone. The nonSACZ regime (generally easterly winds) represented periods when baroclinic systems were transient and did not penetrate into the Tropics. Next, we examine how mesoscale convection in the TRMM-LBA region responded to these regimes.

\section{Radar Rainfall Statistics}

[23] It was argued in the previous section that stationary frontal systems penetrating into the Tropics led to regimes of strong northwesterly flow in the TRMM-LBA region, with easterly or weak westerly winds in the interim. In this section, we explore how mesoscale convection in southwestern Amazônia responded to these regimes. A priori, modulations in precipitation intensity and areal coverage, convective and stratiform fractions of precipitation, vertical 

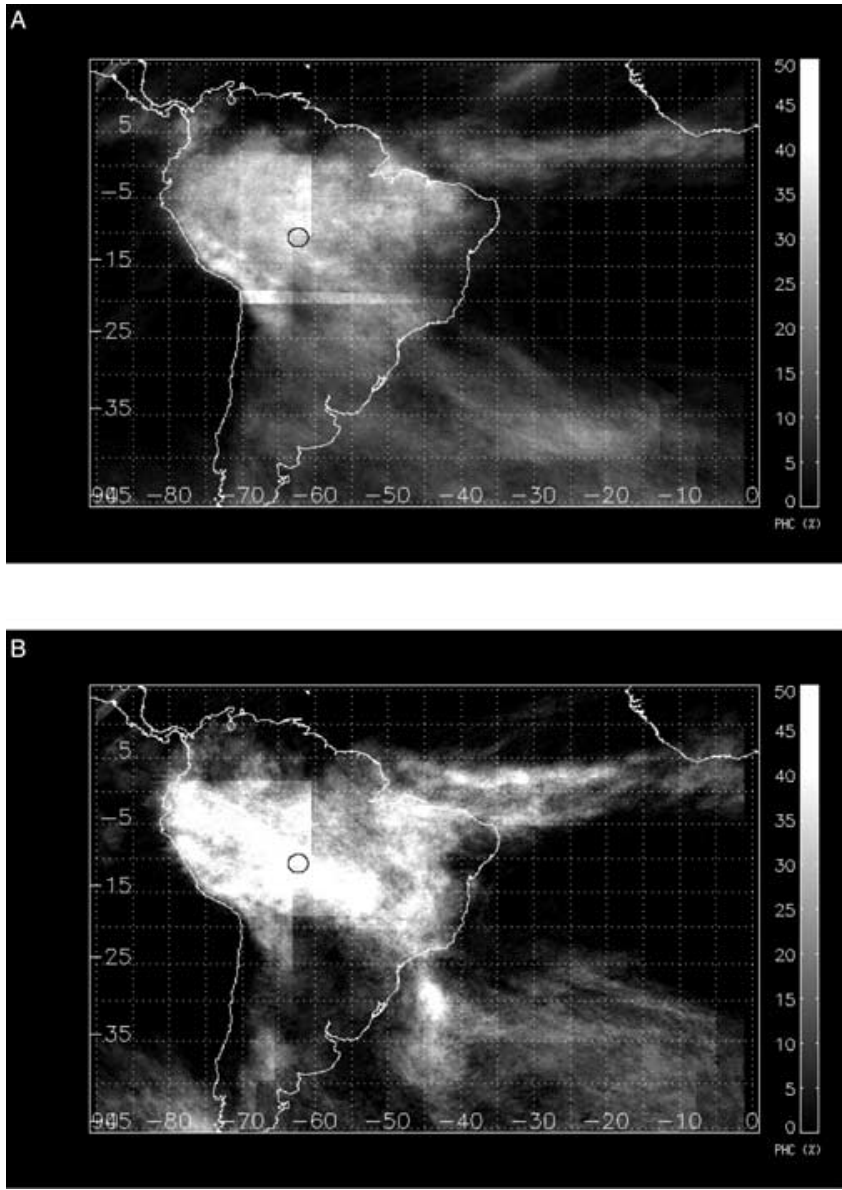

Figure 7. Composites of infrared percent high cloudiness (less than $230 \mathrm{~K}$ ) over South America for (a) the non-SACZ regime periods and (b) the SACZ regime periods. Latitude and longitude lines are shown every $5^{\circ}$. The discontinuities near $20^{\circ} \mathrm{S}, 0^{\circ} \mathrm{N}$, and $60^{\circ} \mathrm{W}$ are artifacts of the construction of the global infrared product. The black circle shows the radar area.

structure, and the diurnal variation of rainfall might be expected in oscillating wind regimes, assuming different thermodynamic properties of the flow source region or different shear profiles. For example, in the tropical western Pacific, the vertical structure and organization of convection responded to changes in tropospheric moisture and wind shear through one cycle of the intraseasonal oscillation [DeMott and Rutledge, 1998; Rickenbach and Rutledge, 1998]. Flow reversal associated with the establishment of the monsoon trough in Darwin, Australia led to weak convective systems dominated by stratiform rain in an oceanic regime of low convective available potential energy [Williams et al., 1992].

[24] We employed surface-based radar data collected during TRMM-LBA to illustrate distinctions in morphology and precipitation of mesoscale convection for the SACZ and non-SACZ regimes. Other parallel studies focused on changes in stability, boundary layer thermodynamics, shear and airflow source properties [Halverson et al., 2002; Betts et al., 2002; Williams et al., 2002; Cifelli et al., 2002].

\subsection{Rainfall and Areal Coverage Time Series}

[25] Shown in Figure 8 was a time series of conditional rainfall rate (TOGA radar) from mid-January to the end of February. Conditional rainfall rate is defined as the rainfall rate at a height of $2 \mathrm{~km}$, averaged over the raining area, and thus is a measure of the areally averaged rain intensity. Spectral analysis of the rainfall time series (not shown) revealed strong diurnal variability, with no clear signal at lower frequencies. In order to examine longer time scale variations, a Fourier decomposition was performed to remove variability of less than eight days (the result is shown as the thick solid curve in Figure 8). Eight days corresponded to the average length of each individual wind regime period. The filtered time series revealed that each of the three westerly wind events were associated with relative minima in rainfall intensity. The minima were particularly evident during $\mathrm{W} 1$ and $\mathrm{W} 3$ (the SACZ regime), while higher rainfall intensities occurred during the easterly wind periods. Application of the Student T-test showed that the mean rainfall intensity was significantly different for the SACZ and nonSACZ regimes with a confidence level of greater than $99 \%$.

[26] Time series of the fraction of the radar's area covered by rainfall (Figure 9) suggested that mesoscale convective systems were, on average, larger during the SACZ periods (with a confidence level greater than 99\%). The low frequency variability corresponded well to that of rainfall intensity. Mesoscale convective systems that occurred during SACZ periods were larger but had weaker rain intensity than those of non-SACZ periods. Similar variability may be seen in the time series of convective rainfall fraction (Figure 10), which was defined as the fraction of the total rainfall associated with convective cells by the convectivestratiform partitioning technique (section 2). Higher values of convective rain fraction indicated more rainfall associated with convective cells compared to lighter and more uniform stratiform rain. The strong diurnal oscillation was a consequence of the evolution of mesoscale convective systems, beginning as isolated convective cells in the late morning and transitioning to stratiform rainfall late in the

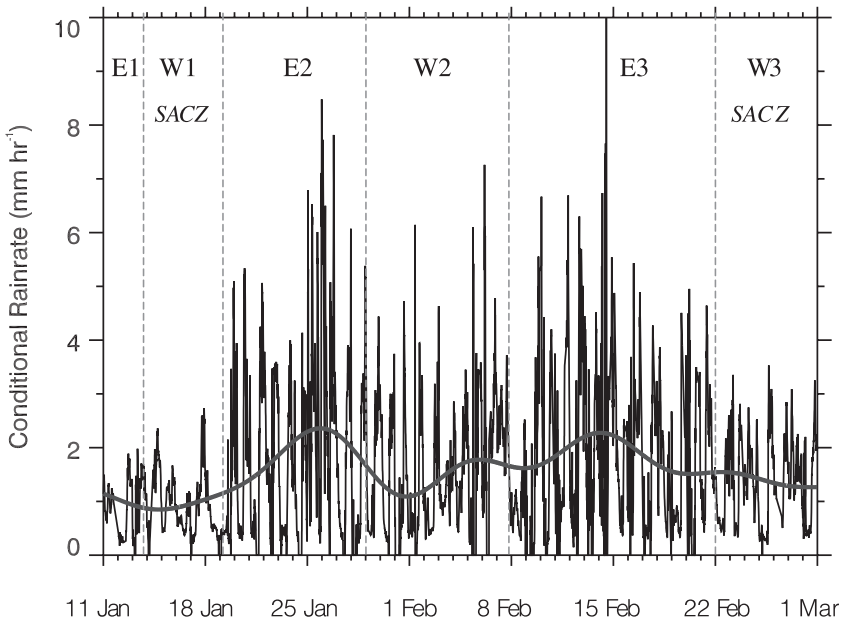

Figure 8. Time series of conditional rainfall intensity $(\mathrm{mm}$ $\mathrm{hr}^{-1}$ ), from TOGA radar data. Thick line is the time series with variations of less than 8 days removed. Regime periods are shown with dashed vertical lines and labels. 


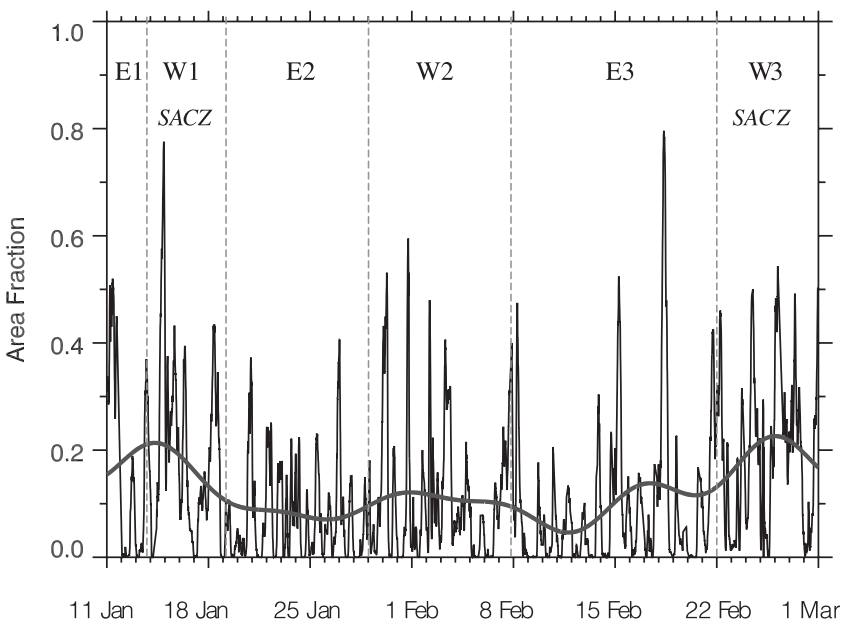

Figure 9. As in Figure 8, but for rainfall areal coverage, defined by the area covered by radar reflectivity values greater than or equal to $10 \mathrm{dBZ}$. Rain area is normalized by the areal coverage of the radar scans.

day (see section 4.3). As with conditional rain rate, the association of low convective rain fractions with the SACZ periods was very clear (greater than $99 \%$ confidence level). These observations showed that mesoscale systems in the SACZ regime were larger, but had weaker rainfall intensity and less convective rainfall than non-SACZ regime systems.

[27] The mean rain intensity, rain area, and the convective versus stratiform partition of these quantities for the SACZ and non-SACZ regimes were summarized in Table 2. The average total (convective and stratiform combined) rainfall intensity for the SACZ regime was $27 \%$ less than that of the non-SACZ regime. Note that the convective rainfall intensity was $47 \%$ lower in the SACZ regime, while the stratiform rainfall intensity was slightly $(10 \%)$ higher. This observation suggested that the difference in rainfall intensity was primarily due to differences in convective cell processes during SACZ periods. This conclusion was supported by the lower mean convective rainfall fraction for the SACZ period (49\%), compared to $66 \%$ for the non-SACZ period. Mesoscale convective systems were, on average, nearly twice as large in areal coverage during SACZ periods, mostly associated with larger stratiform rain areal coverage. Conditions in the SACZ regime clearly favored large, widespread mesoscale convective systems comprised of broad stratiform rain and weak convection. Systems in the non-SACZ regime were smaller, with more intensely precipitating convective cells, associated with propagating squall lines [Cifelli et al., 2002; Silva Dias et al., 2002b].

[28] Interestingly, the PHC composites (Figure 7) implied that high cloud was more common over the radar area in the SACZ regime, even though radar observations showed weaker convective rainfall intensity. This suggested that the increase in high cloudiness during the SACZ period may be more closely tied to the radar-observed increase in stratiform rainfall and areal coverage. The percent high cloudiness at a threshold of $230 \mathrm{~K}$ thus appeared to be more directly related to mesoscale anvil cloud compared to deep convective cells, consistent with observations in the western Pacific Ocean [Yuter and Houze, 1998; Rickenbach, 1999].

\subsection{Vertical Reflectivity Structure}

[29] The mean profile of radar reflectivity with height provides insight as to the intensity of convective updrafts and microphysical processes in mesoscale convective systems [Szoke et al., 1986; Yuter and Houze, 1995]. Vertical reflectivity profiles were calculated for the SACZ and nonSACZ regime. Mean profiles were constructed after converting $\mathrm{dBZ}$ to linear reflectivity factor for each volume, limiting the analysis to below the vertical level (about $13 \mathrm{~km}$ ) where the areal coverage of echo was at least $15 \%$ of the echo coverage at a height of $2 \mathrm{~km}$ to ensure adequate sampling (based on the study of Yuter and Houze [1995]). Separate profiles were constructed for convective and stratiform portions of the echo pattern based on the convective-stratiform partition at a vertical level of $2 \mathrm{~km}$.

[30] The mean reflectivity values for the SACZ regime were lower at all vertical levels than that for the non-SACZ regime (Figure 11). The difference between SACZ versus non-SACZ mean values increased with height in the mixedphase region of the echo, above the nominal $0^{\circ} \mathrm{C}$ level of $4.5 \mathrm{~km}$, for convective, stratiform, and total echo areas. This difference was largest in the convective portion of the systems at upper levels, with a maximum difference of $5 \mathrm{dBZ}$ at a height of $11 \mathrm{~km}$ (difference in mean values were significant to greater than a $99 \%$ confidence level). Below the $0^{\circ} \mathrm{C}$ level, reflectivity differences $(1-3 \mathrm{dBZ})$ were roughly constant with height.

[31] These results suggested that the production of condensate in convective cells in the upper troposphere was enhanced in the non-SACZ regime compared to the SACZ regime. This conclusion was consistent with the findings by Petersen et al. [2002] of higher lightning frequency (which is tied to greater ice mass in the mixed phase region of the convective cells) in the easterly wind (non-SACZ) regimes during TRMM-LBA. Cifelli et al. [2002] found larger vertical updraft speeds in the upper troposphere in easterly regime convective systems compared to westerly regime systems in TRMM-LBA, consistent with the present result. The non-SACZ regime was characterized by larger values of convective available potential energy compared to the SACZ regime, with a capping inversion $1-2 \mathrm{~km}$ above the

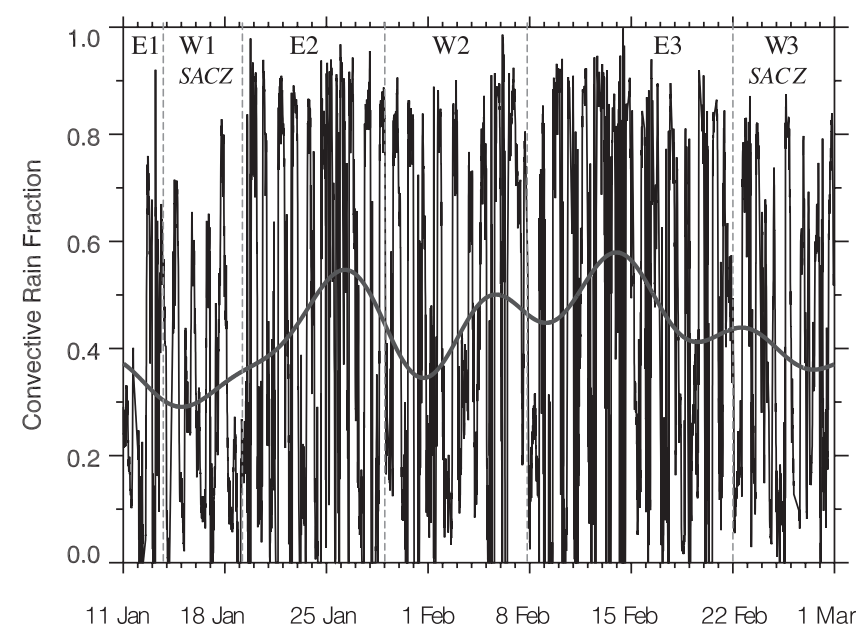

Figure 10. As in Figure 8, but for the fraction of rainfall associated with convective cells (in contrast with stratiform rain). 
Table 2. TOGA Radar Composite Means of Rainfall Intensity, Convective Rain Fraction, and Raining Area for SACZ and NonSACZ Regimes, From TOGA Radar Data ${ }^{\mathrm{a}}$

\begin{tabular}{lccc}
\hline \multicolumn{3}{c}{ Composite rainfall and rain area values } \\
\hline Rain intensity & & SACZ & Non-SACZ \\
& Total & 0.73 & 1 \\
& Convective & 0.53 & 1 \\
Convective rain & Stratiform & 1.1 & 1 \\
fraction & & $49 \%$ & $66 \%$ \\
Rain area & Total & 1.9 & 1 \\
& Convective & 1.3 & 1 \\
& Stratiform & 2.0 & 1 \\
\hline
\end{tabular}

${ }^{\mathrm{a}}$ Values of rain intensity $\left(\mathrm{mm} \mathrm{hr}^{-1}\right)$ and rain area $\left(\mathrm{km}^{2}\right)$ were normalized to the means for the non-SACZ regime.

surface [Halverson et al., 2002], consistent with more explosive convection, stronger vertical drafts, and higher condensate mass in the upper troposphere.

\subsection{Diurnal Composites}

[32] Composites of the diurnal variation of rainfall intensity and precipitation areal coverage (Figures 12 and 13) provided further insight into the differences in mesoscale convection for the SACZ and non-SACZ regimes. The diurnal composites were partitioned by convective and stratiform components, as discussed earlier. Both regimes were typified by a sharp increase in rainfall intensity between 1000 and 1200 local time, all in the convective
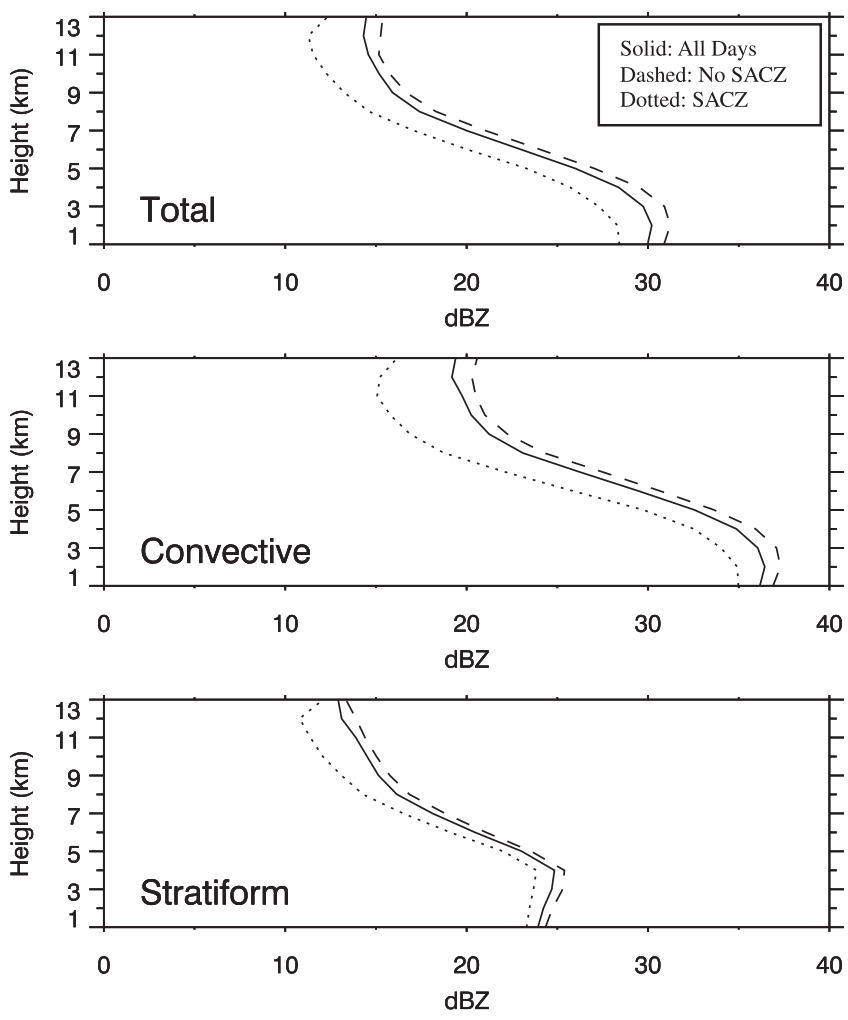

Figure 11. Mean vertical profiles of radar reflectivity for the entire experiment (solid line), the SACZ regime (dotted line), and the non-SACZ regime (dashed line). The three panels show profiles for total, convective, and stratiform radar echo.
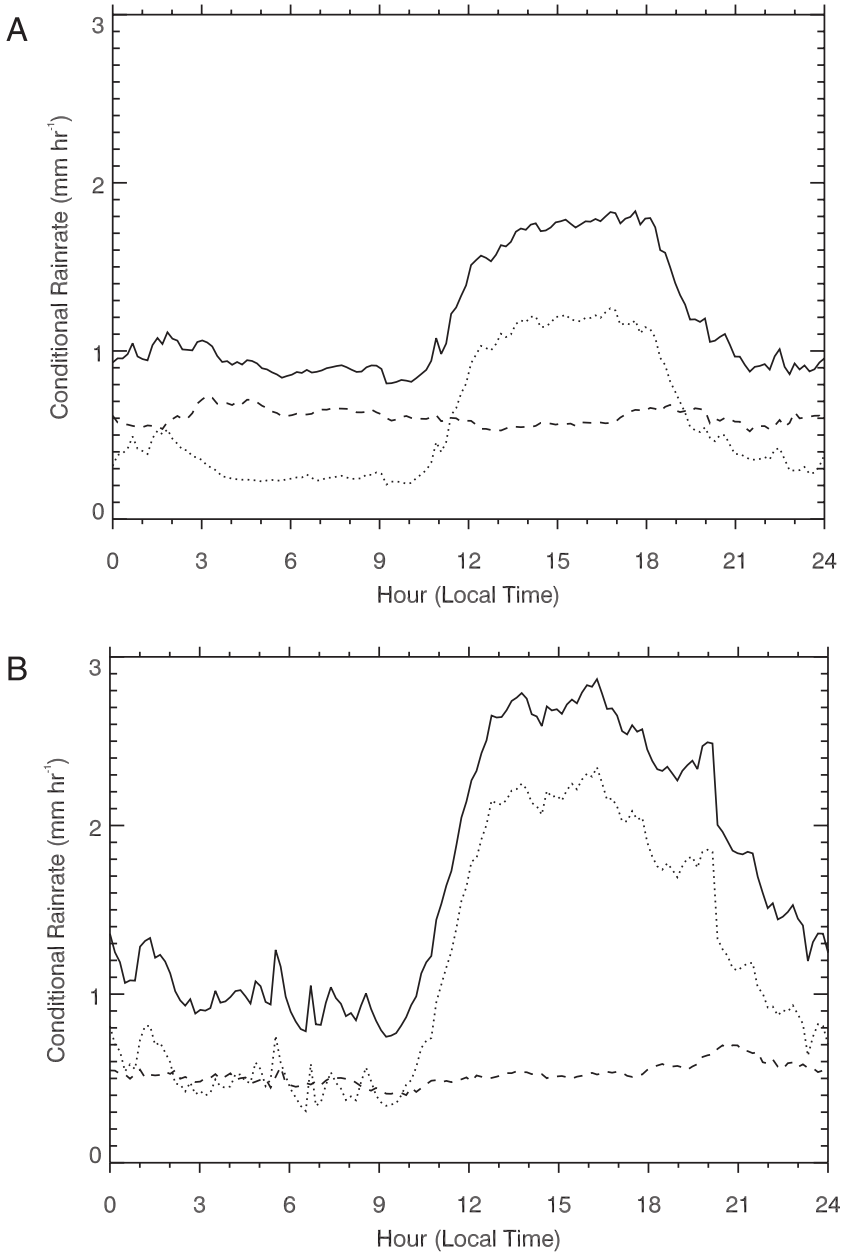

Figure 12. Diurnal variation of conditional rainfall rate $\left(\mathrm{mm} \mathrm{hr}^{-1}\right)$ for (a) the SACZ regime and (b) the non-SACZ regime. Solid line is total rain, dotted line is convective rain, and dashed line is stratiform rain.

component of rainfall. The increase was faster and larger in the non-SACZ regime, consistent with the large contrast in convective intensity implied by the vertical reflectivity profiles shown in Figure 11, and the strong updrafts of a non-SACZ (easterly) regime case [Cifelli et al., 2002]. The maximum rainfall occurred between about 1500 and 1700 local time in each regime. The timing of the diurnal cycle was generally consistent with a 17 year record (1979-1996) of rain gauge data at Ji Parana (the TRMM-LBA region) presented by Liebmann et al. [1998], and to an analysis of rain gauge data during TRMM-LBA [Betts et al., 2002].

[33] The stratiform rain intensity displayed a weak early evening maximum (2100 local time) in the non-SACZ regime. This observation may reflect the several-hour time delay between peak convective rain rate and the peak in stratiform rain area, typical of the life cycle of organized squall line systems [McAnelly and Cotton, 1989]. As convection decayed, the stratiform area increased after local midnight (Figure 13). It was not clear whether this was due to the life cycle effect, since there were two nocturnal squall line systems (15 and 18 February) that may have contributed to the increase in stratiform rain area. In contrast, the stratiform rain intensity of the SACZ regime remained 

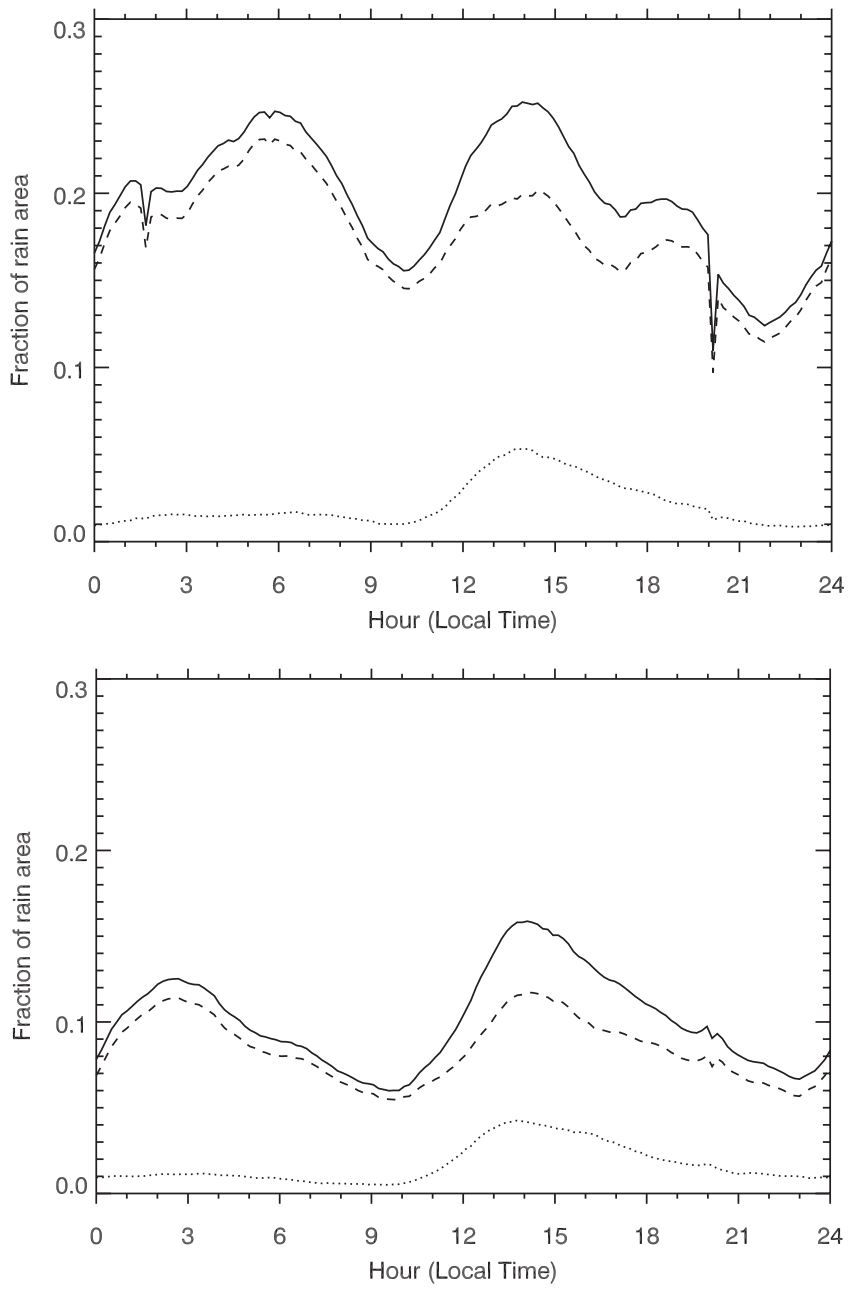

Figure 13. As in Figure 12, but for the fraction of the radar scan area covered by rain.

constant throughout the day and night, and actually exceeded the convective rain intensity at night. This suggested that the nocturnal maximum in stratiform areal coverage, also present in the SACZ regime, may have been due to a nocturnal resurgence of stratiform due to mechanisms independent of convective cells, such as radiative or large-scale dynamical processes. There were at times field observations of weak but extensive nocturnal stratiform precipitation events, with no obvious convective source, which formed after local midnight and persisted into the morning hours. Conspicuous events occurred on 18 January, between 2 and 5 February, and between 24 and 26 February, all during westerly periods. These nocturnal stratiform events had characteristics of shallow stratocumulus drizzle. Detailed case studies should shed more light on the mechanisms of the complex features present in the diurnal variation of precipitation.

\section{Conclusions}

[34] The alternating regimes of low-level easterly and westerly winds observed locally over southwestern Amazônia were related to large-scale changes in the circulation patterns over South America. Distinct westerly wind events in the lower troposphere observed during the TRMM-LBA field campaign were shown to be local manifestations of baroclinic wave influence on tropical latitudes during the summer season. The strong low-level northwesterly winds observed during mid-January and late February 1999 were a local signature of northwesterly flow along a stationary frontal zone that defined the South Atlantic Convergence Zone. Drawing upon the scenario presented by Garreaud [2000], the northwesterly flow ahead of frontal zones transported moist air from the equatorial Amazon basin southeastward into the subtropics. This pattern was clearly demonstrated in the large-scale patterns of circulation, moisture convergence, and cloudiness during the SACZ periods. In contrast, the northwesterly flow branch during non-SACZ periods was weaker in magnitude and remained outside of the deep Tropics (poleward of $15^{\circ} \mathrm{S}$ latitude). This suggested that baroclinic waves extended much deeper into tropical latitudes, with stationary frontal zones penetrating the interior of Amazônia during the SACZ periods. The non-SACZ periods were characterized by frontal systems that were transient and did not extend into the deep Tropics.

[35] These contrasting large-scale flow patterns had important consequences for mesoscale convection in southwestern Amazônia. In the TRMM-LBA region, mesoscale convective systems during the SACZ regime produced $27 \%$ less rainfall, mainly due to weaker convective rain intensity, but were on average twice as large in area compared to systems in the non-SACZ regime. Time series of these parameters indicated a remarkable correspondence with the wind regimes. Differences in the profiles of radar reflectivity in the upper portion of convective cells suggested that the non-SACZ environment was more conducive to stronger convective updrafts in the upper troposphere. Diurnal variation of rain intensity and rain area suggested explosive growth of afternoon convection in the non-SACZ regime. The diurnal results for the SACZ regime hinted at the possibility that the large-scale environment, not convective processes, enhanced the stratiform rain process at night. Furthermore, Petersen et al. [2002] suggested that the relationship between mesoscale convection and flow regime shown here appeared to be present in other years, implying a more general result.

[36] Other studies of TRMM-LBA convection were consistent with these observations, though the physical mechanisms for differences in mesoscale convection in each wind regime were not clear. Petersen et al. [2002] presented observations of significantly higher lightning flash rates (indicative of enhanced vertical intensity of convection) during the non-SACZ (easterly) regimes, while Cifelli et al. [2002] showed that updrafts in a non-SACZ (easterly) regime convective system were much stronger than an SACZ (westerly) regime counterpart. Another study pointed to differences in the thermodynamic environment between the regimes [Halverson et al., 2002]. They suggested that dry midlevel air, present in easterly flow, introduced convective inhibition into the thermodynamic profile that, given sufficient boundary layer moisture and a triggering mechanism, led to explosive convection. As low-level wind direction alternated between westerly and easterly, the concentrations of cloud condensation nuclei changed, with "cleaner" low-level air in westerly regimes leading to less 
frozen condensate in the upper portions of convective clouds and weaker electrification [Williams et al., 2002]. Mesoscale circulations associated with elevated topography west of the TRMM-LBA area may have provided a favored region for the formation of mesoscale convective systems [Laurent et al., 2002]. Boundary layer evolution differed significantly between forest and pasture regions [Silva Dias et al., 2002a]. These studies implied that as the low-level flow direction reversed, thermodynamic properties of the source air and mesoscale circulations associated with topography or land-type contrasts could lead to changes in the mesoscale organization of convection. We also speculate that fundamentally different tropospheric shear profiles in each regime may also have played a role. For example, during the westerly regime, the motion of convective systems was opposite to the upper tropospheric flow. This might lead to large system-relative displacements between condensate ejected from convective cells and the location of new cell growth, resulting in large areal coverage of precipitation.

[37] The differences in mesoscale convection in the SACZ and non-SACZ regimes in southwestern Amazônia was reminiscent of the contrast between "monsoon period" versus "break period" (respectively) wet season convection in Darwin, Australia near the maritime continent [Williams et al., 1992]. In Darwin, the establishment of the monsoon trough brought moist oceanic air with low convective available potential energy over Northern Australia, resulting in widespread stratiform rainfall with weak embedded convection compared to the intense squall lines of the break period. In Amazônia, the South Atlantic Convergence Zone, with the associated penetration of stationary frontal circulations into the Tropics, was the analog to the monsoon trough in Darwin, responsible for periodic low-level flow reversals. The present study suggested that, in southwestern Amazônia, the flow direction reversal in the SACZ regime led to precipitation characteristics similar to that of the Darwin monsoon regime. The northwesterly SACZ regime flow may have tapped air with "oceanic" characteristics (low convective available potential energy, low concentrations of cloud condensation nuclei) from the forested interior of the Amazon basin [Williams et al., 2002; Halverson et al., 2002], resulting in convection with properties like those of the Darwin monsoon. We further hypothesize that during the SACZ regime, large-scale ascent along a stationary frontal zone may have provided the lifting needed to produce widespread stratiform rain in the absence of intense deep convection. Despite the parallels between convective regimes in Northern Australia and Amazônia, we suggest that while flow regimes in Darwin were modulated by the position of the monsoon trough, baroclinic systems controlled the flow regimes in southwestern Amazônia.

[38] These results imply that the SACZ strongly influences how Amazon convection transports heat vertically, which may guide improvements to the parameterization of subgrid-scale convective processes associated with wet season Amazon basin convection in general circulation models. Furthermore, the large difference in mesoscale convective system structure for different synoptic regimes at a single tropical continental location has implications for the improvement of precipitation and latent heating retrieval from the TRMM satellite. For example, TRMM algorithms might require "tuning" at a given location if large-scale analysis suggested monsoon or frontal forcing. The basis of such modifications is the subject of future research.

[39] Acknowledgments. This project was funded by grants from the NASA Tropical Rainfall Measuring Mission (TRMM) and from the NASA Large-Scale Biosphere Atmosphere (LBA) Hydrology Project. We wish to acknowledge helpful discussions with Alan Betts, Dennis Boccippio, Robert Cifelli, George Kiladis, Jose Marengo, Andrew Negri, Walt Petersen, and Earle Williams. The comments of the anonymous reviewers significantly improved the presentation of the results. Thanks to David Wolff of the TRMM Satellite Validation Office for help with the radar data processing and quality control. Geostationary satellite data was obtained from the Global Hydrology Resource Center (GHRC) at the Global Hydrology and Climate Center, Huntsville, AL, USA, and Carlos Morales aided in working with this data set.

\section{References}

Anagnostou, E. N., C. A. Morales, and T. Dinku, The use of TRMM precipitation radar observations in determining ground radar calibration biases, J. Atmos. Oceanic Technol., 18, 616-628, 2001.

Betts, A. K., J. D. Fuentes, M. Garstang, and J. H. Ball, Surface diurnal cycle and boundary layer structure over Rondonia during the rainy season, J. Geophys. Res., 107, 10.1029/2000JD000356, in press, 2002.

Casarin, D. P., and V. E. Kousky, Anomalias de precipitação no sul do Brasil e variações na circulação atmosférica, Rev. Bras. Meteorol., 1, $83-90,1986$.

Chen, M. H., R. B. Rood, and J. Joiner, Assimilating TOVS humidity into the GEOS-2 data assimilation system, J. Clim., 12, 2983-2995, 1999.

Cifelli, R., W. A. Petersen, L. D. Carey, and S. A. Rutledge, Radar observations of the kinematic, microphysical and precipitation characteristics of two MCSs in TRMM-LBA, J. Geophys. Res., 107, 10.1029/ 2000JD000264, in press, 2002.

Climanálise, Boletim de monitoramento e análise climática, vol. 14, 1-2. Available from Centro de Previsão de Tempo e Estudos Climáticos, Rodovia Presidente Dutra, km 240 SPRJ, 12630-000, Cachoeira Paulista-SP, Brasil, 1999.

Demott, C. A., and S. A. Rutledge, The vertical structure of TOGA COARE convection, part II, Modulating influences and implications for diabatic heating, J. Atmos. Sci., 55, 2748-2762, 1998.

Figueroa, S. N., P. Satyamurty, and P. L. D. Silva Dias, Simulations of the summer circulation over the South-American region with an ETA-coordinate model, J. Atmos. Sci., 52, 1573-1584, 1995.

Gandu, A. W., and J. E. Geisler, A primitive equations model study of the effect of topography on the summer circulation over tropical South America, J. Atmos. Sci., 48, 1822-1836, 1992.

Garreaud, R. D., Cold air incursions over subtropical South America: Mean structure and dynamics, Mon. Weather Rev., 128, 2544-2559, 2000.

Grimm, A. M., and P. L. Silva Dias, Analysis of tropical-extratropical interactions with influence functions of a barotropic model, J. Atmos. Sci., 52, 3538-3555, 1995.

Halverson, J. B., T. M. Rickenbach, B. Roy, H. Pierce, and E. Williams, Environmental charcteristics of convective systems during TRMM-LBA, Mon. Weather Rev., 130, 1493-1509, 2002.

Herdies, D. L., A. da Silva, and M. A. F. Silva Dias, The bi-modal pattern of the summertime circulation over South America, J. Geophys. Res., 10.1029/2001JD000997, in press, 2002.

Houze, R. A., Jr., Observed structure of mesoscale convective systems and implications for large-scale heating, Q. J. R. Meteorol. Soc., 115, 435461, 1989.

Kodama, Y.-M., Large-scale features of subtropical convergence zones (the Baiu frontal zone, the SPCZ, and the SACZ), part I, Characteristics of subtropical frontal zones, J. Meteorol. Soc. Jpn., 70, 813-835, 1992.

Kousky, V. E., and M. A. Gan, Upper tropospheric cyclonic vortices in the tropical South Atlantic, Tellus, 33, 538-551, 1981.

Laurent, H., L. A. T. Machado, C. A. Morales, and L. Durieux, Characteristics of the Amazonian mesoscale convective systems observed from satellite and radar during the WETAMC/LBA experiment, J. Geophys. Res., 10.1029/2001JD000337, in press, 2002.

Lenters, J. D., and K. H. Cook, Summertime precipitation variability over South America: Role of the large-scale circulation, Mon. Weather Rev., 127, 409-431, 1999.

Liebmann, B., J. A. Marengo, J. D. Glick, V. E. Kousky, I. Wainer, and O. Massambani, A comparison of rainfall, outgoing longwave radiation, and divergence over the Amazon Basin, J. Clim., 11, 2898-2909, 1998.

Liebmann, B., G. N. Kiladis, J. A. Marengo, T. Ambrizzi, and J. D. Glick, 
Submonthly convective variability over South America and the South Atlantic Convergence zone, J. Clim., 12, 1877-1891, 1999.

Marengo, J., B. Liebmann, V. Kousky, L. Filizola, and I. Wainer, Onset and end of the rainy season in the Brazilian Amazon Basin, J. Clim., 14, $833-852,2001$

Marks, D. A., et al., Climatological processing and product development for the TRMM ground validation program, Phys. Chem. Earth, Part B, 25(10-12), 871-875, 2000.

McAnelly, R. L., and W. R. Cotton, The precipitation life cycle of mesoscale convective complexes over the central United States, Mon. Weather Rev., 117, 784-807, 1989.

Nogues-Paegle, J. N., and K. C. Mo, Alternating wet and dry conditions over South America during summer, Mon. Weather Rev., 125, 279-291, 1997.

Olson, W. S., C. D. Kummerow, Y. Hong, and W.-K. Tao, Atmospheric latent heating distributions in the Tropics derived from satellite passive microwave radiometer measurements, J. Appl. Meteorol., 38, 633-664, 1999.

Petersen, W. A., et al., TRMM observations of convective regimes in the Amazon, J. Clim., 15, 1278-1294, 2002.

Rickenbach, T. M., Cloud-top evolution of tropical oceanic squall lines from radar reflectivity and infrared satellite data, Mon. Weather Rev., 127, 2951-2976, 1999.

Rickenbach, T. M., and S. A. Rutledge, Convection in TOGA COARE: Horizontal scale, morphology and rainfall production, J. Atmos. Sci., 55 2715-2729, 1998.

Silva Dias, P. L., W. H. Schubert, and M. DeMaria, Large-scale response of the tropical atmosphere to transient convection, J. Atmos. Sci., 40, 26892707,1983

Silva Dias, M. A. F., et al., Clouds and rain processes in a biosphere atmosphere interaction context in the Amazon Region, J. Geophys. Res., 10.1029/2001JD000335, in press, 2002a.

Silva Dias, M. A. F., et al., A case study of convective organization into precipitating lines in southwest Amazon during the WETAMC and TRMM-LBA, J. Geophys. Res., 10.1029/2001JD000375, in press, 2002b.

Steiner, M., R. A. Houze Jr., and S. E. Yuter, Climatological characterization of three-dimensional storm structure from operational radar and rain gauge data, J. Appl. Meteorol., 34, 1978-2007, 1995.

Szoke, E. J., E. J. Zipser, and D. P. Jorgensen, A radar study of convective cells in mesoscale systems in GATE, part I, Vertical profile statistics and comparison with hurricanes, J. Atmos. Sci., 43, 182-197, 1986.

Thorncroft, C. D., B. J. Hoskins, and M. E. McIntyre, Two paradigms of baroclinic life-cycle behaviour, Q. J. R. Meteorol. Soc., 119, 17-55, 1993.

Tokay, A., W. Krajewski, and A. Perreira Filho, Measurements of drop size distribution in southwest Amazon region, J. Geophys. Res., 10.1029/ 2001JD000355, in press, 2002

Williams, E. R., S. A. Rutledge, S. G. Geotis, N. Renno, E. Rasmussen, and T. Rickenbach, A radar and electrical study of tropical "hot towers", $J$. Atmos. Sci., 49, 1386-1395, 1992

Williams, E., et al., Contrasting convective regimes over the Amazon: Implications for cloud electrification, J. Geophys. Res., 107, 10.1029/ 2001JD000380, 2002.

Yuter, S. E., and R. A. Houze Jr., Three-dimensional kinematic and microphysical evolution of Florida cumulonimbus, part II, Frequency distributions of vertical velocity, reflectivity, and differential reflectivity, Mon. Weather Rev., 123, 1941-1963, 1995.

Yuter, S. E., and R. A. Houze Jr., The natural variability of precipitating clouds over the western Pacific warm pool, Q. J. R. Meteorol. Soc., 124, 53-99, 1998.

Zhao, Y., and B. C. Weare, The effect of diurnal variation of cumulus convection on large-scale low-frequency oscillations in the Tropics, $J$. Atmos. Sci., 51, 2653-2663, 1994.

J. B. Halverson and T. M. Rickenbach, Joint Center for Earth Systems Technology (JCET), University of Maryland, Baltimore County and NASA Goddard Space Flight Center (GSFC) Mesoscale Processes Branch, Greenbelt, MD, USA. (rickenba@umbc.edu)

R. N. Ferreira, Goddard Earth Sciences and Technology Center (GEST), University of Maryland, Baltimore County and NASA Seasonal to Interannual Prediction Project/GSFC, Greenbelt, MD, USA.

D. L. Herdies, Goddard Earth Sciences and Technology Center (GEST), University of Maryland, Baltimore County and NASA Data Assimilation Office/GSFC, Greenbelt, MD, USA.

M. A. F. Silva Dias, Department of Atmospheric Science, Institute of Astronomy and Geophysics, University of São Paulo, São Paulo, Brazil. 